\title{
京都における文化財を含む地域の 土砂災害危険領域に関する一考察 \\ PREDICTION OF SEDIMENT HAZARDS ZONE IN THE RESIDENTIAL AREA WITH CULTURAL HERITAGE IN KYOTO CITY
}

\author{
伊藤隆郭1 江頭進治 2 •コーシャル・ラジェ・シャーマ3 \\ Takahiro ITOH, Shinji EGASHIRA and Kaushal Raj SHARMA \\ ${ }^{1}$ 正会員 博士 正学) 立命館大学理工学部都市システム工学科 講師 『5 525-8577 草津市野路東1-1-1)
${ }^{2}$ フェ口一会員 工博 立命館大学理工学部都市システム工学科 教授 『5 525-8577 草津市野路東1-1-1)
学生員 工修 立命館大学理工学研究科総合理工学専攻 『 $525-8577$ 草津市野路東1-1-1)
}

A preliminary study is conducted to propose countermeasures for residential areas with cultural heritage as well as for residential area against sediment hazards such as landslide and debris flow, focusing on part of Kyoto City. Firstly, the spreading of residential area in Kyoto City is discussed using both a latest topographic map and an old map published before about 90 years. Secondary, in order to obtain the simple and physically reasonable methods for evaluating the sediment hazards, the validities of predictions obtained using the governing equations of mass point system for soil block's dynamics is confirmed in terms of the calculated results using $1 \mathrm{D}$. governing equations of debris flow and the data obtained by field investigations.

A critical line of sediment hazards zone predicted using momentum conservation equations of mass point system suggests that occurrences of sediment disaster are inevitable in present residential regions and, additionally, several cultural architectures are located in sediment hazards zone.

Key Words : flood disaster, landslide, debris flow, hazards map, cultural heritage, Kyoto city

\section{1. 緒言}

1950年以後 ,日本において50人以上の死者 行方不 明者を出した豪雨災害の発生頻度をみると,1950年代 には35回，1960年代には18回，1970年代には8回， 1980年代には5回および1990年代には1回のように減少 している1)。一方，1982年の長崎豪雨災害 ,1983年の山 陰豪雨災害,1990年代の鹿児島豪雨災害, 広島豪雨 災害,さらには,2004年7月の新潟・福島豪雨,福井豪 雨,台風10号,9月の台風21号, 10月の台風23号と続い た豪雨災害に見られるように,中小河川の汇濫や土砂 災害に伴谈害力頻発しており,局地性，地域性の強い 災害か顕在化している.このよ沈災害を防止 軽減する ためには，災害を引き起こす物理現象の解像度を1ラン ク引き上げた現象の評価が必要である.さらに,文化遺 産を有する歴史都市においては，現象の解像度と共に， 災害外力の設定法を再評価する必要があると思われる. 本研究においては，国宝·重要文化財か滵集する京 都を対象として，降雨や地震などを契機として発生する 崩壊 ・土石流による土砂災害の対策指針を得ることを目 的とし，次のような解析を行う.まず,文化財を含む地域 の土砂災害ポテンシャルを検討するため，市内における 文化財の分布と市街地の拡大状況を調べる.次に，簡
便で,かつ，合理的な土砂災害危険領域に関する解析 法を検討するために，崩土 ·土石流の質点系および1次 元支配方程式を用いて得られる計算結果を比較検討し， 乥れらの支配方程式の特性を明らかにする.さらに，質 点系の支配方程式を用いて土砂災害データを解析し， その適用性について議論する.最後に, 京都市域の一 部を抽出して, 質点系の支配方程式に基づいて土砂災 害危険領域に関する解析結果を示す．

\section{2. 京都における市街地の拡大と文化財の分布}

著者らの以前の研究 ${ }^{2), 3)}$ によれば,洪水 対象として，次のような結果が得られている.まず,総雨 量か約100 mmを越えると,府下のどこかで家屋が流失・ 全壤するよ沈災害か溌生し,降雨量か滋 $120 \mathrm{~mm}$ 程度 になると,人命が失われる災害が発生する可能性がある. 次いで,死者行方不明者数と全壤 流失家屋数の間に は明瞭な相関があり,光れらは死者 行方不明者数の上 限值と下限值を示す2本の包絡線に挟まれた領域で表 現される.なお，上限を示す包絡線に近い程，土砂災害 の特性を表し，下限に近い程，洪水氾濫を主体とした災 害特性を表している.これらの結果を踏まえた上で,京 都市域の市街地の変遷についてみる. 
図－1は，京都市域における 土地利用の在り方を概観する ため, 現在の市街地に1909年 明治42年 $)^{4)}$ および1930〜 1932年 眧和5 7年)の市街地 を重ねたものである.同図には 国宝·重要文化財に指定され ている絵画 彫刻や建造物など の分布も示している.

まず,市街地についてみると， 1909年当時には北部，西部お よび南部には集落が島状に点 在しているが, 現在では, 島状 の集落群が消滅して都市化が 進展していることが分かる.これ は,土砂災害を受けやすい急 傾斜地への市街地化とともに , 桂川,鴨川および宇治川の氾 濫域への都市化が進展してい ることを示している。

次いで,文化財の分布につ いてみる.文化財の多〈は， 1909年当時の市街地の領域内 に分布していることが分かる. 更に，文化的建造物に着目し てみると,これらは1909年当時 の市街地の中心部には殆どな く,周辺の北部と東部に集中し ているのが分かる.これは, 応仁 の乱などの戦火や天明の大火

(788年)等が原因で绡失したようである゙．

文化的建造物か特に集中している東山一帯に着目す ると,この一帯においては,急傾斜地が多く,土砂災害 ポテンシャルが高いものと推察される.乥こで,この地域 の文化財を含む市街地の土砂災害危険度について検 討する.なお，ここでは，位置が比較的移動しない文化 財として建造物を対象とする。

\section{3. 土砂災害危険領域の解析}

\section{(1) 崩土の支配方程式と艺の特性}

崩壊 ・土石流の発生，場所およびその規模を予測する ことは，極めて困難な状況にある.しかしながら，弚れら が発生した後の土塊の移動開始から停止するまでの過 程はある程度評価できる段階にある(6)-10).これには，質 点系,1次元および2次元の連続体の支配方程式と構成 則を用いて崩土の移動過程を評価する方法がある.な お,微地形の影響か顕著でない場合, 崩土の移動距離 を1次元的に追跡する計算結果と2次元的に追跡するも のを比べると,崩土の面的な拡がりを考慮しない分だけ， 1 次元的に追跡される崩土の移動距離の方が大きく見 積もられる.ここでは,計算方法が簡便である質点系の 運動方程式を用いる.この理由については，後述する． なお，ここでは，崩土の運動と土石流を区別せずに取り 扱い,渓床を移動する土塊を土石流とみなす．

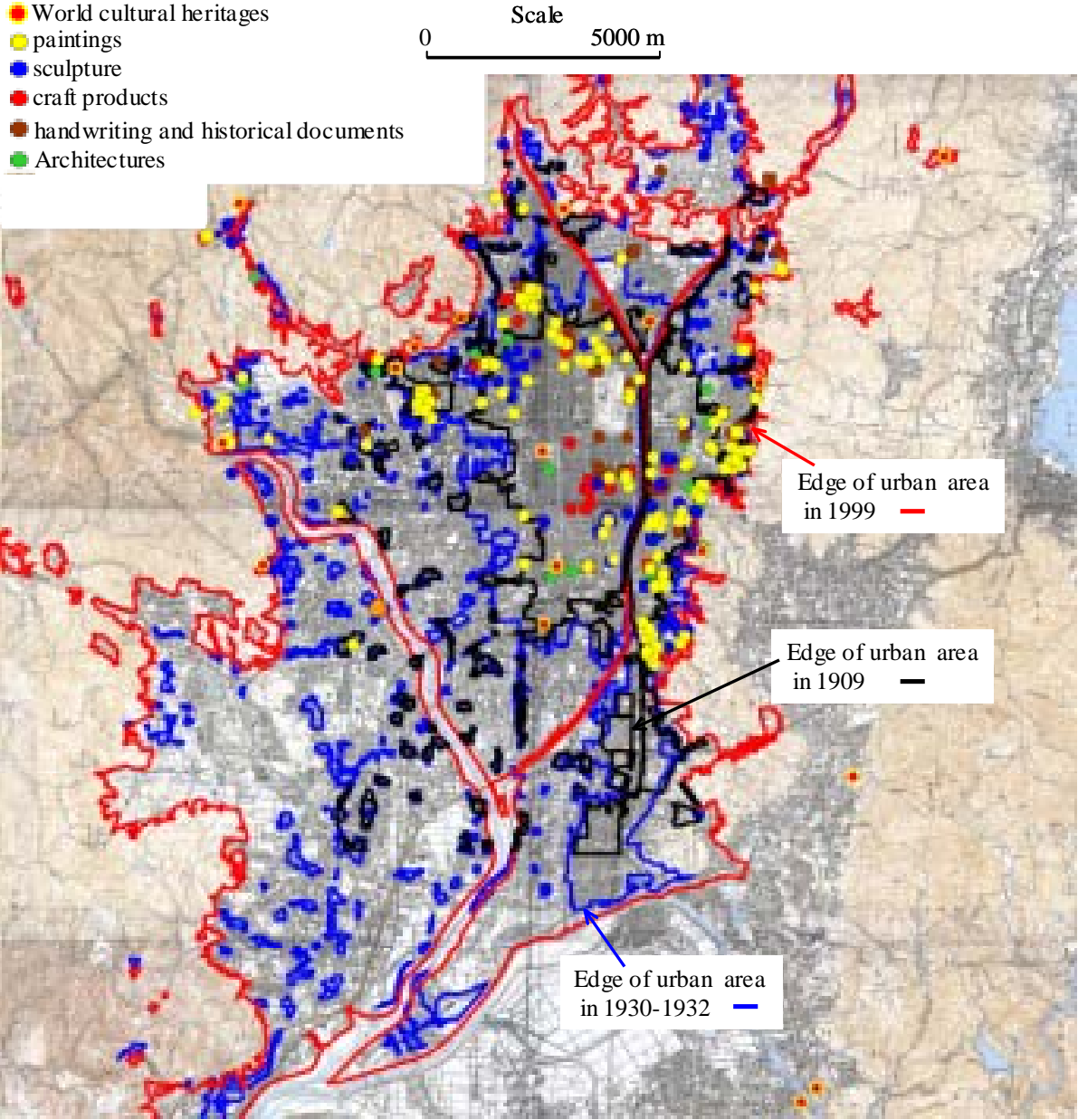

图 - 1 京都における約90年間の市街地の拡大と文化財の分布状況 (国土地理院発行の $1 / 25,000$ 地形図と古地図 ${ }^{4)}$ を用いている)

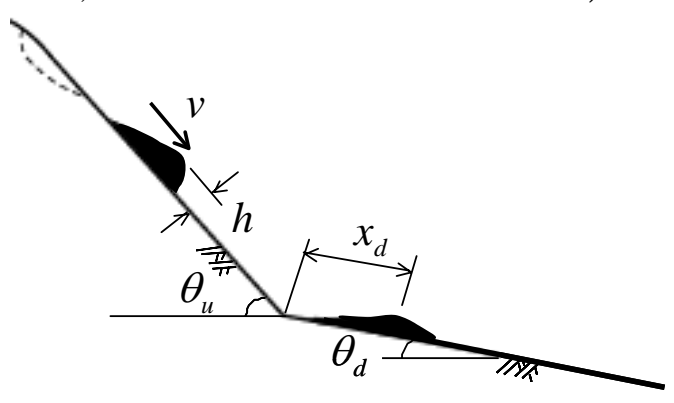

图 - 2 崩土の移動 停止に関する模式図

图 - 2は, 斜面上を運動する崩土の運動に関する模式 図である.崩壊は勾配 $\theta_{u}$ の斜面で発生し,崩土が勾配 $\theta_{d}$ の領域で停止する状況を示している.崩土が水て飽 和し,崩土の形状の相似性が保たれるものとして,運動 方程式が得られている ${ }^{10)}$.これに対し，侵食 堆積に伴 櫍量および運動量輸送を考慮すれば,崩土の支配方 程式は次のようこ与えられる2).

質量保存則)

$$
\begin{aligned}
& \text { 土粒子と水の混合物 }: \frac{d h}{d x}=\frac{1}{2 k} \frac{E}{c_{*} v} \\
& \text { 土粒子 }: h \frac{d c}{d x}=\frac{1}{k}\left(1-\frac{c}{c_{*}}\right) \frac{E}{v}
\end{aligned}
$$


世粒子と水の運動量保存則)

$$
\begin{aligned}
& v \frac{d v}{d x}=g \sin \theta-\frac{(\sigma-\rho) c}{\rho_{m}} g \cos \theta \tan \phi_{s} \\
& -\frac{\rho f_{b} v^{2}}{\rho_{m} k h}-\frac{v E}{k h}\left\{\frac{\sigma-\rho}{\rho_{m}}\left(1-\frac{c}{c_{*}}\right)+\frac{1}{c_{*}}\right\}
\end{aligned}
$$

ここに, $h$ は崩土の厚さ, $c$ は土粒子の体積濃度,$v$ は 移動速度， $c_{*}$ は崩土の静止堆積濃度， $\sigma$ は土粒子の 質量密度, $\rho$ は水の質量密度, $\rho_{m}$ は崩土を構成する 土粒子と水の混合物の密度で, $\rho_{m}=c \sigma+(1-c) \rho$ のように定義される. $\phi_{s}$ は土粒子の内部摩擦角， $f_{b}$ は 崩土の流動抵抗係数, $k$ は形状係数で, 崩土の長さを $l$,崩土の面積を $A$ とすると, $A /(l h)$ のように定義され， 崩土が三角形のときには， $k=0.5, g$ は重力の加速度， $\theta$ は斜面勾配， $x$ は流れ方向に沿った座標， $E$ は侵食 率 侵食速度)である.なお,式(1)〜(3)においては,時 間 $t$,距離 $x$ および速度 $v$ を用いて,$d / d t=v d / d x$ の よ汭変換か施されている.

式 ()〜式 B)において $E$ および $f_{b}$ が与えられれば 式系か閉じる.乥こで,江頭らの土石流に関する侵食率 の表示式と抵抗則 ${ }^{8)}$, 9), 11) を適用すると次式のようである.

$$
\begin{gathered}
\frac{E}{v}=c_{*} \tan \left(\theta-\theta_{e}\right) \\
\tan \theta_{e}=\frac{(\sigma-\rho) c}{(\sigma-\rho) c+1} \tan \phi_{s} \\
f_{b}=\frac{25}{4}\left\{k_{d} \frac{\sigma}{\rho}\left(1-e^{2}\right) c^{1 / 3}\right. \\
\left.+k_{f} \frac{(1-c)^{5 / 3}}{c^{2 / 3}}\right\}\left(\frac{h}{d}\right)^{-2}
\end{gathered}
$$

ここに, $e$ は土粒子間の反発係数,$d$ は崩土の土粒子 の代表粒径, $k_{d}=0.0828, k_{f}=0.16$ である.

式(1)〜式(3)の支配方程式は，質点系のものであるた め,崩土の重心の運動を追跡することになる.ここで， 崩土の流動過程において, 侵食 堆積の影響か顕著 ではないものと仮定すると,式形は単純化されて,運動 方程式は次式のように表される(10),12).

$$
\begin{aligned}
v \frac{d v}{d x}= & g \sin \theta-\frac{(\sigma-\rho) c}{\rho_{m}} g \cos \theta \tan \phi_{s} \\
& -\frac{\rho f_{b} v^{2}}{\rho_{m} k h}
\end{aligned}
$$

式 6)は無次元速度 $v^{\prime}$ および無次元距離 $x^{\prime}$ を用い て整理すると,次式のよう変換される.

$$
v^{\prime} \frac{d v^{\prime}}{d x^{\prime}}=\cos \theta\left\{\tan \theta-\frac{(\sigma-\rho) c}{(\sigma-\rho) c+\rho} \tan \phi_{s}\right\}
$$

$$
\begin{gathered}
-\frac{1}{k} \frac{\rho f_{b} v^{\prime 2}}{(\sigma-\rho) c+\rho} \\
\text { ここに, } v^{\prime}=v / \sqrt{g h}, x^{\prime}=x / h \text { である. }
\end{gathered}
$$

式 ヤ)から明らかなよう, 崩土は斜面あるいは渓床の 勾配がある限界值よりも緩くなると停止する.钅の勾配の 限界值は,式 ヤ)の右辺第1項が負になる条件，すなわ ち,次式で与えられる。

$$
\tan \theta<\frac{(\sigma-\rho) c}{(\sigma-\rho) c+1} \tan \phi_{s}
$$

式(8)において, 崩土を構成する土粒子の濃度を代入す ると, 崩土が停止する斜面の限界勾配 (止限値)か求め られる。

以上のように,崩土の運動に関する質点系の支配方 程式と炎の特性について紹介した .ここで,今後検討す べき幾つかの課題について示すと次のようである.

まず,崩土の移動過程における侵食や堆積の影響を 考慮した場合には，土石流の1次元および2次元解析と 同樣であるが,計算に際して不確定なパラメータである 渓床や斜面を構成する表土層の厚さの分布を取り込む 必要がある.この設定は,現地の特性を十分に調査した 上で行われる必要がある.

次に，斜面を構成する土砂の物理特性に関する事項 である.上述の支配方程式を適用する際には，土砂は 非粘着性の材料として取り㸝っている.しかしながら,崩 土の移動開始点近傍の渓床 斜面勾配は, 通常, 非粘 着性の土砂の安息角以上であることが多いことから,粘 着力をもつ材料の侵食抵抗は非粘着性材料のものより も大きくなると推察される.これは, 斜面や渓床の材料で 擾乱をあまり受けていない材料の侵食に対しても同樣で あると考えられる.江頭ら ${ }^{13)}$ は，広島土石流災害の解析 において，まさ土に対して上述の考え方を適用し解析を 試みている.すなわち,式(4)に示す移動床の平衡勾配 $\theta_{e}$ の評価において粘着性力を加え,式(4)よりも平衡勾 配を大き〈することによって,侵食抵抗を増加させている.

\section{(2) 質点系の支配方程式の適用性}

式(6)および式(7)の支配方程式は, 崩土の重心の運 動を追跡するものであり,光の規模が大きくなると, 到達

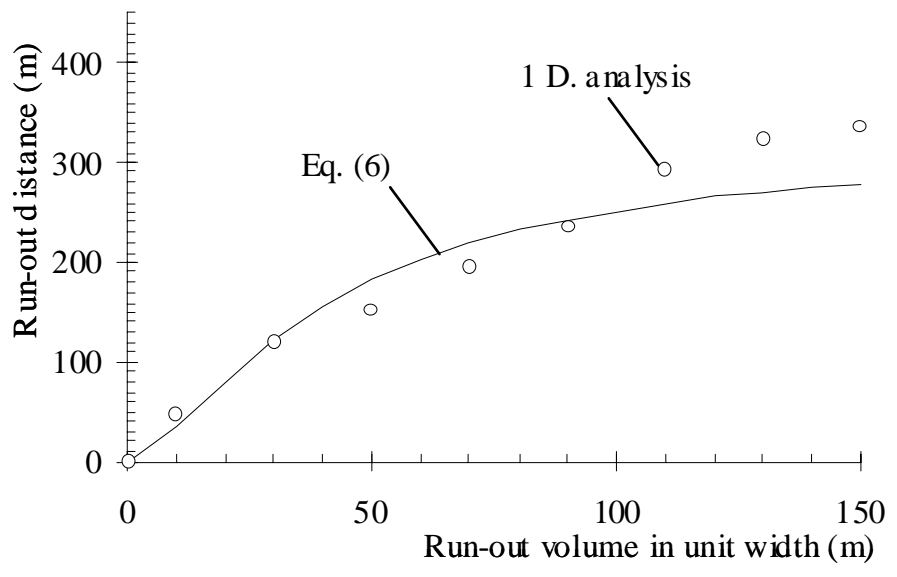

図 - 3 単位幅あたりの崩土体積と崩土の移動距離の関係 
距離の評価に際して先端部と重心の位置の違い は無視できなくなる.ここでは,まず，光れらの影響 について検討する.次いで, 質点系の運動方程式 を現地の土砂災害事例に適用し, 兴の適用性に ついて検討する。

图 -3は, 崩土の到達距離に着目し, 崩土の運 動を移動方向に連続する流れとして扱 j1次元解 析法 ${ }^{10), 14)}$ による結果と式 (6)による結果を比較し たものである.計算においては， $\theta_{u}=30^{\circ}$ ， $\theta_{d}=5^{\circ}, k=0.5, \phi=34^{\circ}, \sigma=2.65 \mathrm{~g} / \mathrm{cm} 3$, $\rho=1.0 \mathrm{~g} / \mathrm{cm} 3, c_{*}=0.52, c=0.4, e=0.85$, $d=20 \mathrm{~cm}$ とている.いずれの計算においても, 傾斜角 $\theta_{u}$ をもつ斜面の長さは, 移動速度の定常 值が形成されるよう十分に長くとられている.さらに， 1次元解析法による計算において,土石流先端部 と土砂堆積前面の位置の平均値を到達 距離としている.同図によれば,崩土の到 達距離の計算値は,単位幅当たりの崩壤 土量が $10^{2} \mathrm{~m}^{2}$ を越えるような規模の大きい 崩壤を対象としない限り,質点系と1次元 解析の結果はほぼ一致している。

次に,豪雨を契機として発生した崩壞や 土石流に伴计砂災害に対して,質点系 の支配方程式を適用し,崩土の停止距離 に着目した解析を行う.ここでは,2004年9 月29日に台風21号に伴儫雨によって発 生した三重県宮川村の土砂災害を対象と する。

同村の災害の詳細は,文献 ${ }^{15)}$ に譲るこ とにするが,概要は次のようである.台風 21 号の影響により日本海側に停滞してい た前線が活発化し,三重県南部で発生・ 発達した活発な雷雲が県内を南から北へ 進行することにより,宮川村周辺に豪雨が もたらされた.宮川雨量観測所では,29日 の午前9時〜 10時の間に時間雨量が約 $120 \mathrm{~mm}$,連続雨量か760 mm程度の雨量 か観測されている.この豪雨を契機として， 同村を流れる宮川の両岸の小滝, 滝谷, 唐櫃地区などで崩壤・土石流が発生した。 これにより,裏山に近接した斜面下部近 傍の家屋が被災し，死者行方不明者か7 人となる土砂災害となった .

图－4は,土砂災害が発生した斜面や 支渓のうち4つを抽出して,5000分の1の地形 図を用いて得られた河床標高の縦断分布である.図中 における矢印の位置は, 崩土の移動開始点であり, これ らは,空中写真および現地調査によって特定している。 なお，各支渓および斜面の最下流端は宮川河岸であり， 滝谷地区の宮川右岸側の支渓をTakiya (R) ,小滝地区 の宮川右岸の支渓をKotaki (R) ,小滝地区の宮川左岸 の斜面をKotaki (L), 雲母谷の支溪をKirara creekのよう に表記している.なお，いずれの支渓 斜面においても，

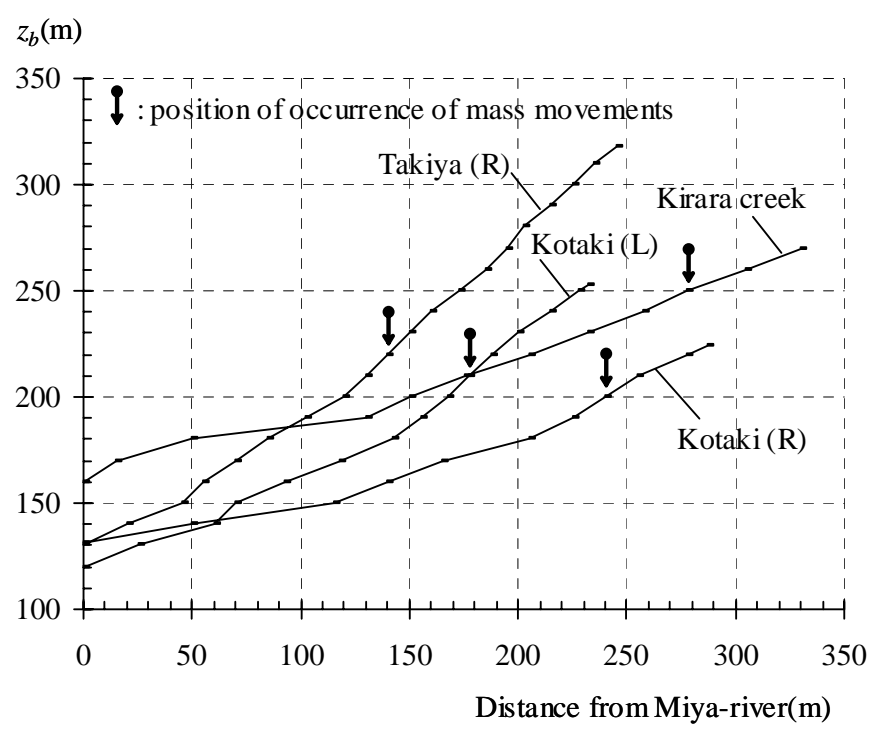

图 -4 宮川に接続する支渓の縦断图 E重県宮川村) $z_{b}(\mathrm{~m}) \quad$ Kirara creek
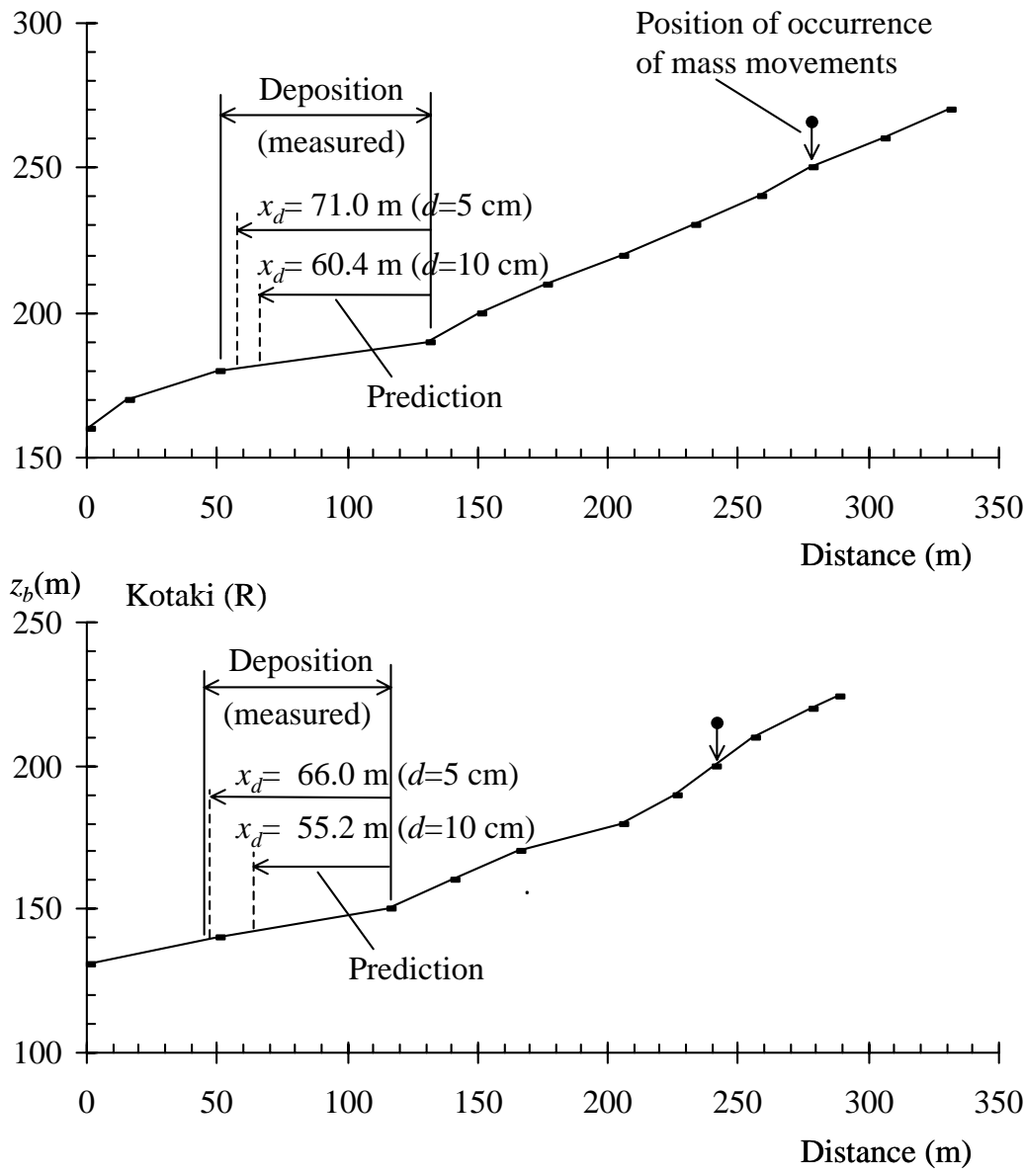

図 - 5 崩土の停止距離に関する現地データと計算値の比較

崩土の移動過程で觅床の侵食 堆積か顕著でなかった ことを確認している.ここでは,雲母谷の支渓および小滝 地区の宮川右岸の支溪に関する結果を示す．

图 - 5は,崩土が停止可能斜面に到達してから停止す るまでの到達距離 図一2の $x_{d}$ ) について,式(6)を用い た計算值と現地データを比較したものである.なお，現 地データは, 空中写真および現地調査により, 崩土が停 止し始めたと判読される地点と停止位置に存在する崩 
土の先端近傍の区間を土砂停止範囲とすることによって 求められている.同図には,光の範囲を'Deposition'とし て示している.一方, 計算において, 河床勾配は, 図一 4の河床縦断図を用いて求め,現地調査の結果を基に して $, h=2 \mathrm{~m}, d=10 \mathrm{~cm}, c=0.52$ のよう二設定して いる.弚の他のパラメーターは図 - 3の計算に用いたも のと同じである.同図には,比較のために,$d=5 \mathrm{~cm}$ の 結果も示している.また, 矢印で示す崩土の移動開始点 は, 渓床の最急勾配程度の位置で,かつ, 空中写真に よって特定された位置としている.崩土の停止開始点は, 河床勾配が式(8)を満たす最上流の地点とし,光こから の崩土の到達距離 $x_{d}$ の計算值を図中に示している.

同図によると,式(6)による崩土の停止距離の計算結果 は,現地データよりも若干小さい.式(6)は崩土の重心位 置を表すものであり,崩土の長さ,崩土の堆積変形およ び若干の渓床侵食の影響を考慮すると妥当な結果が得 られている.例えば,崩土厚 $h=2 \mathrm{~m} て ゙$, 崩土の長さ $l=20 \mathrm{~m}$ とすと,重心の停止位置から $10 \mathrm{~m}$ 下流側が崩 土の到達先端となる.この結果を图 - 5に適用すると, 崩 土の先端部の到達位置はほぼ一致している.

图 - 3と図 - 5の結果を総合すると,単位幅当たりの崩 壞土量が $10^{2} \mathrm{~m}^{2}$ 程度までの規模で,侵食 堆積の影響 カ湿著ではない崩土の運動については,式(6)あるいは
式(7)の質点系の支配方程式を用いた解析によって,崩 土の到達範囲を評価可能であることが示された .次節に おいては,式(6)を用いて, 崩土の到達範囲の解析を行 うことよって ,土砂災害危険領域の解析を行う.

\section{（3）京都を対象とした災害危険領域の解析}

表層崩壊は,一般に $30^{\circ}$ 以上の斜面で発生すること が知られており (10), 16)，このような斜面を崩壊可能斜面と して抽出する.崩壊可能斜面から等高線に直角に交わ るように落水線を引き, 弚の縦断図を作成し,最急勾配 の地点で崩壊が発生するものとして,式 6)を適用すれ ば，個々の落水線上において崩土の移動速度およびそ の停止点が求められる.これらの停止点を連ねた線の山 側の領域が土砂災害危険領域に相当する.式 \$)〜式 『)から明らかなよう，停止点の位置は, 崩土の厚さ $h$ が大きい程, または, 崩土の粒径 $d$ が小さい程, 到達距 離は大きくなる。

图－6は,東山地域の一部について災害危険領域の 解析を行った結果である.図には,1909年および現在の 市街地の外緑を示すとともに，比較的小さい崩壊を想定

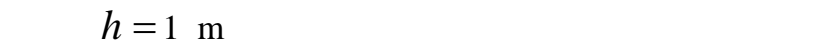
の大きいものを想定して,$h=3 \mathrm{~m}$ とした崩土の到達線 に関する計算值が示されている.これらの線よりも山側 の領域が危険領域であると見なされる.なお，計算に用

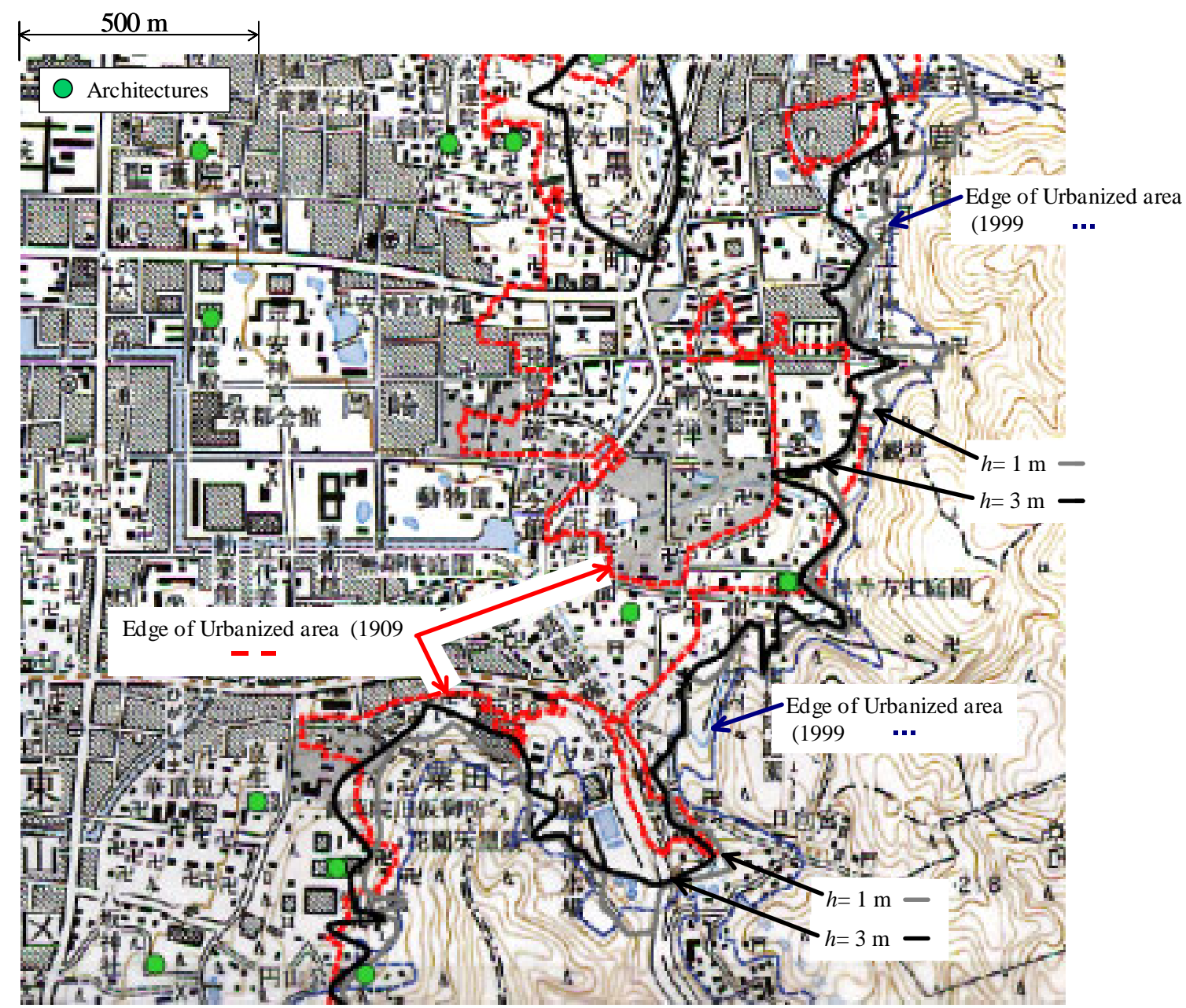

图 - 6 質点系の運動方程式を用いた土砂災害危険領域の解析例 京都市東山地区の一部) (国土地理院発行の1/25,000地形図と古地図 ${ }^{4}$ を用いている) 
いた勾配以外のパラメーターは ,图-3に用いたものと 同じである.同図によれば，1909年当時の市街地は危 険領域まで伸びていなかったものの，現在では2つの限 界線よりも山側まで伸びており，いくつの文化的建造 物も危険領域に存在している.事実，これまでの東山一 帯における災害被災事例をみると,土砂移動に伴揵造 物の被災例が報告されており,乥れらが危険領域に存 在しているものもある.

なお，上述の算定法からも分かるように，危険領域が 一樣に色険性をもっている訳ではなく，災害危険度は落 水線上に存在する崩壊可能斜面における崩壊の起こり やすさや落水線の密度等に依存する ${ }^{10), 17) .}$.危険領域に 立地する文化財や市街地の災害対策を詳細に行うため には, 更なる調査が必要と思われる.しかしながら, 図 6に示したような解析に基づいて，文化財や关の周辺市 街地の景観を損なわない程度の災害対策, 例えば,家 屋移転などを行うことによって緩衝領域のような空間を 設けること等の必要性は議論できるものと推察される.同 図における解析法および觉の解析例は, 今後の土地利 用の在り方を議論する上での重要なものと思われる .

\section{4. 結語}

本研究においては,文化的建造物を含む地域の土砂 災害防止 軽減対策を検討するための端緒として,デー 多解析および数值解析を行った.本研究によって得られ た成果を列挙すると次のようである.

(1) 江頭らの質点系の支配方程式に基づき,山腹の表 層崩壊に伴计砂災害の危険領域を設定する方法を提 示すると共に,光れを土砂災害データと比較することに よって,弚の適用性を確認した。

(2) 京都市内の一部を抽出して,危険領域の解析を行 い,文化的建造物を含む市街地の災害危険性を示した . これによれば,1909年当時には危険領域には市街地は なかったものの，今日では危険領域の内部へ伸びてき ているとともに，乥こには文化的建造物も存在しているこ とが明らかにされた。

以上のような成果が得られたものの，災害の防止軽 減対策をきめ細か〈行い,今後の土地利用の在り方に 対して議論をするには，危険領域における危険度階級 などの解析が必要と思われるが,今後の課題としたい.

謝辞 : 本研究を推進するに当たり,文化財の分布調査 等においては,立命館大学理工学部 恛生 古田 大君 辎 京都市) ,鈴木俊雄君 辎 国土交通省中部地方整 備局天竜川上流河川事務所)に協力頂いた.現地およ び現地データの整理においては,立命館大学理工学研 究科博士前期課程1回生の太井正史君,立命館大学理 工学部4回生 鶴田直也君, 西窪久弥君に協力頂いて いる.さらに,三重県環境森林部,県土整備部河川室お よび砂防室の諸兄には,三重県宮川村の土砂災害関 連データを御提供頂いている.最後に,本研究の一部 は,文部科学省 21 世紀COEプログラム 文化遺産を核と した歴史都市の防災研究拠点: 研究代表者 村橋正
武)の研究拠点形成費補助金によって推進されている. ここに記して感謝致します。

\section{参考文献}

1) 国立天文台 理科年表 ,丸善,2005.

2) Egashira, S., T. Itoh and Kaushal Raj Sharma: Distribution of cultural heritages and residential region in sediment hazard zone, Proceedings of the International Conference on Monitoring, Prediction and Mitigation of Water-Related Disasters (MPMD), January 12-15, Disaster Prevention Research Institute of Kyoto University, pp. 667-672.

3) 江頭進治 伊藤隆郭・コーシャル・ラジェ・シャーマ:京都に おける文化財を含む地域の土砂災害危険領域の解析， 日本水文科学会誌,35巻,3号,pp. 119-127,2005.

4) 柏書房 :正式二万分一地形図集成 関西),2001.

5）土岐憲三 :自然災害から文化遺産を守るー見過ごされて いた視点一, 国連防災世界会議パブ将フォーラム シン ポジウム講演集 文化遺産を災害から守るために」,文化 遺産防災連絡会議 ,pp. 12-17,2005.

6) 高橋 保 ·里深好文:石礫型及び乱流型土石流の一般理 論と炎の実用化モデル, 砂防学会誌, Vol. 55 ,No. 3 ,pp. 33-42,2002.

7）椿 東一郎 橋本晴行 林次忠司 :土石流における粒子間 力と流動特性, 土木学会論文報告集, 317,pp. 79-81， 1982 .

8) Egashira, S., K. Miyamoto and T. Itoh: Constitutive equations of debris flow and their applicability, Proceedings of the 1st International Conference on Debris Flow Hazards Mitigation, ASCE, pp. 340-349, 1997.

9) 江頭進治·宮本邦明 伊藤隆郭:掃流砂量に関する力学 的解釈, 水工学論文集, 41巻,pp. 789-794,1997.

10) 土木学会編 水理公式集 ,pp. 144-145, 1999.

11) Egashira, S., N. Honda, T. Itoh: Experimental study on the entrainment of bed material into debris flow, Physics and Chemistry of the Earth (C), EGS, Vol. 26 (9), pp. 645-650, 2001.

12) Egashira, S. and K. Ashida: The dynamic behavior of a soil block on slope, Proc. Int. Symp. on Erosion, Debris Flow and Disaster Prevention, Sept., Tsukuba, Japan, pp. 249254, 1985.

13) 江頭進治 ·本田尚正 高濱淳一郎伊藤隆郭 有村真一 : 土石流の再現および構造物による土石流調節について， 1999年6月西日本の梅雨前線豪雨による災害に関する調 査研究 研究代表者 福岡捷二), 文部省科学研究費特 別研究促進費(1)成果報告書,pp. 83-102,2000.

14) Itoh, T., K. Miyamoto and S. Egashira: Numerical simulation of debris flow over erodible bed, Proceedings of the 3rd International Conference on Debris-Flow Hazards Mitigation, pp. 457-468, 2003.

15) 林 拙郎ら 2004年9月29日,台風21号に伴って発生した 三重県宮川村の土砂災害 速報), 砂防学会誌,Vol. 57 , No. 4 ,pp. 48-55,2004.

16) 例えば,江頭進治 昭和57年7月豪雨による土砂災害につ いて, 京都大学防災研究所年報,第26号, A ,pp. 1-17， 1983 .

17) 例えば,江頭進治中 庸充·内田 修 斜面崩壊に伴谈 害危険度の評価法に関する研究, 砂防学会誌 新砂防), Vol. 49 ,No.3 ,pp.11-19,1996 .

2005.9.30 受付) 